take the practical steps necessary to make mediation a widespread and permanent practice inside the Church of England.

doi:10.1017/So956618X10000815

\title{
The Regulation of Islamic Finance in the United Kingdom
}

\author{
JONATHAN ERCANBRACK ${ }^{1}$
}

Doctoral Student, School of Oriental and African Studies, University of London

\section{INTRODUCTION}

This article examines the unique risks associated with Islamic financial institutions and the secular state's reticence to directly regulate their religious dimension. It argues that the state's method of regulating the Islamic financial industry ignores special reputational risks associated with the religious and cultural distinctiveness of Islamic banks.

The Financial Services Authority (FSA), the body responsible for the authorisation and regulation of all financial services in the United Kingdom, applies conventional regulatory criteria and product definitions in authorising Islamic financial institutions. Yet these banks differentiate themselves from their conventional peers in that they house so-called Sharia supervisory boards. Sharia boards' principal remit is to audit products and services for their compatibility with Islamic principles, which developed over the course of centuries of Islamic jurisprudence. Products that comply with such principles earn the 'Islamic' label, which is crucial to their uptake by Muslim investors. Therefore, Sharia boards' direct responsibility for the religious interests of Muslim consumers creates a unique reputational risk in such institutions insofar as banks found to have contravened the Sharia may trigger a lack of confidence in them.

The article proceeds in highlighting these issues by first addressing the current state of Islamic finance in the UK and the government's objectives in creating an Islamic financial centre. Second, the government's modus operandi in facilitating and regulating Islamic finance is scrutinised with respect to the

1 The author would like to thank Sham Qayyum and Anna Kallioinen for their generous help in reviewing this article. 
determining factor of Islamic financial institutions: the role of Sharia compliance. Finally, a review of English courts' adjudication of Islamic financial transactions is provided, elucidating the courts' unwillingness to apply the Sharia in cases in which Sharia compliance is in question.

\section{ISLAMIC FINANCE IN THE UK}

The flow of Middle Eastern capital to the City of London has been accompanied by the rise of Islamic finance, an alternative form of financing that purports to structure its contracts and financial services according to Islam's holy law, the Sharia. The Sharia forbids the taking of interest and speculative transactions such as derivatives, and seeks to create value through real, tangible assets. Moreover, companies involved in the sale of pork, alcohol, pornography, gambling, some forms of entertainment, and corporations with large interestgenerating investments are forbidden to Islamic investment. Islamic financial products are engineered by melding together a series of age-old classical Islamic contracts so as to comply with the conventional regulatory system and to compete in highly competitive global financial markets. While the products and services offer Muslim investors similar economic returns to conventional products, their underlying legal structures and corresponding risks are markedly different.

The UK government has skilfully pursued the creation of an Islamic subeconomy, which it prefers to call 'alternative financial investments', by enacting legislative and regulatory measures designed to facilitate Islamic financial transactions. A concerted and wide-ranging governmental effort is underway by a number of authorities who have established working groups to advise the government on Islamic finance. Her Majesty's Treasury has established the HM Treasury Islamic Experts Group, and HM Revenue and Customs (HMRC) formed the HM Revenue and Customs Islamic Finance Group. Furthermore, the UK Trade and Investment agency is actively promoting Islamic financial services and, in particular, the City of London's leading position in the growing field. ${ }^{2}$

Legislative measures have largely focused on amending tax provisions for Islamic financial structures in that these contracts acquire and dispose of tangible assets, commonly in sale and repurchase schemes that transfer title in property multiple times. Hence, the first legislative measure was to amend stamp duty land tax so as to facilitate Islamic finance's most utilised structure, the murabaha - a sale plus mark-up scheme - that hitherto was disadvantaged on account of its tax treatment. On the regulatory front, the government has

2 'Country Focus: United Kingdom - Open Door Policy' (2007) 164 (April-June) New Horizon: Global perspectives on Islamic banking and insurance 24-28. <http://www.islamic-banking.com/resources/ 7/NewHorizon\%20Previouse\%2oIssues/NewHorizon_AprJuno7.pdf>, accessed 1 October 2010. 
found it appropriate to enact very few regulatory provisions that address the unique contractual features of Islamic finance. The FSA, ${ }^{3}$ the universal regulator of all financial services in the UK, applies a conventional risk-based approach to the industry, which stresses economic substance over legal form. However, the religious and cultural aspects of Islamic finance constitute the primary reasons for Muslims' uptake of these products. Thus, a uniform regulatory treatment may overlook or obviate some of the unique characteristics associated with the industry.

Britain now houses five domestic Islamic financial institutions which claim to offer Sharia-compliant financial products and services and the City of London has established itself as the third largest market for Islamic finance after the Gulf Co-operation Council states and Malaysia. Yet the history of Islamic banking in the United Kingdom is fairly recent. ${ }^{4}$ HSBC launched its amanah current account and home financing products in 2003 and Lloyds TSB also introduced a range of Islamic retail banking products. Not until 2004 did the FSA license the Islamic Bank of Britain, which purports to be the first wholly Sharia-compliant retail bank in the United Kingdom. ${ }^{5}$ Since then four other Islamic financial institutions have been authorised, including the European Islamic Investment Bank and, most recently, Gatehouse Bank, a wholesale Islamic financial institution. Moreover, at least nine Islamic fund managers, one Sharia-compliant hedge fund manager, a takaful insurance provider $^{6}$ and a growing number of advisory firms in the legal, accountancy and consultancy professions are active in the UK.?

\section{THE GOVERNMENT'S OBJECTIVES}

The UK government offers two reasons for its regulatory strategy: First, it hopes to establish an Islamic financial centre in the City of London and thus maintain

3 The newly-elected Conservative government has announced that the FSA will be disbanded. In its place a new Prudential Regulatory Authority within the Bank of England will oversee prudential regulatory concerns while a separate Consumer Protection and Markets Authority will focus on the protection of consumers. The new regulatory system will come online in 2012.

4 R Wilson, 'Islamic banking in the United Kingdom' in M Fahim Khan and M Porzio (eds), Islamic Banking and Finance in the European Union (Cheltenham, 2010), p 212. In the early 1980 os a number of Middle Eastern Islamic banks established subsidiaries in the UK, which conducted wholesale operations. Banks such as Saudi International Bank and the United Bank of Kuwait accepted deposits on a murabaha cost-plus basis and conducted short-term trades on the London Metal Exchange.

5 NS\&I, Sharia Compliant Savings Review (2008), pp 1-22. < http://www.nsandi.com/files/asset/pdf/ sharia'a_savings_review.pdf $>$, accessed 1 October 2010.

6 Conventional insurance is widely prohibited according to Islamic law as it entails a strong element of speculation and/or excessive risk known as gharar. Takaful insurance offers Muslims a form of communal insurance whereby premiums are pooled in investment projects and disbursed as gifts or donations to compensate a member's claim.

7 HM Treasury, The Development of Islamic Finance in the UK: the Government's perspective (London, 2008), pp 1-30. 
London's status as Europe's premier financial centre, and indeed, one of the leading financial centres in the world. ${ }^{8}$ Specifically, the development of a thriving and competitive market in Islamic financial products could substantially benefit the United Kingdom by generating further investment, jobs and indirect tax revenues in the economy. ${ }^{9}$ Secondly, the government seeks to include a large domestic Muslim minority in the financial marketplace. While eight out of ten of most minority groups in the United Kingdom have accounts with financial institutions - compared with nine out of ten of the majority population only two-thirds of those of Pakistani origin and just over half of those of Bangladeshi origin do. ${ }^{10}$ Research attributes these statistics to Muslims' beliefs in abstaining from interest-based financial transactions although many British Muslim respondents often argue that interest-based activities are permissible with respect to loans and non-essential consumption. ${ }^{11}$

The state's policy of facilitating the Islamic financial industry may also help to incorporate unregulated Islamic financial activities whose market participants are otherwise deprived of regulatory and consumer protections ${ }^{12}$ and whose financial activities undermine the state's fiscal and monetary policies. Indeed, some minority groups have traditionally sought financial advice, borrowing and lending within the community on the basis of recommendations and kinship networks. In effect, informal credit unions have been established in many areas housing large minority populations. ${ }^{13}$ Moreover, research concerning hawala money transfer systems highlights a complex web of global traders whose ability to transfer money to the far reaches of the globe undercuts the nation-state's ability to keep tabs on its citizens' monetary activities. ${ }^{14}$ Informal Islamic commercial transactions reflect the limits of state law as it may be weakened by the allegiance of subjects to competing legal norms and value systems. ${ }^{15}$ In co-opting Islamic financial practices Muslim minorities may feel that they should and can behave in a way that conforms to the

8 City of London, Global Financial Centres 7 (London, 2010). <http://www.zyen.com/PDF/GFC\%207. pdf $>$, accessed 1 October 2010.

9 HMRC, Impact Assessment for Stamp Duty Land Tax, Capital Gains \& Capital Allowance Tax Reliefs for Alternative Finance Investment Bonds (London, 2009). <http://www.hmrc.gov.uk/budget2009/ afi-bonds-100.pdf $>$, accessed 1 October 2010.

10 P Meadows, Access to Financial Services (London, 2000), pp 1-34.

11 Ibid $\mathrm{p}$ 17. Other, less often cited reasons for doing so relate to the classical differentiation between dar al harb (abode of war) and dar al Islam (abode of peace). Some classical jurists argued that interest could be accepted from infidels in the dar al harb, ie non-Muslim territories.

12 HMRC, Impact Assessment, p 5.

13 Meadows, Access to Financial Services, p 17.

14 R Ballard, 'Coalitions of reciprocity and the maintenance of financial integrity within informal value transmission systems: the operational dynamics of contemporary hawala networks', (2005) 6 Journal of Banking Regulation 319. See also R Ballard, 'The operation of contemporary informal value transfer (hawala) systems', (unpublished, 2007).

15 A Allot, The Limits of Law (London, 1980), p 148. See also W Menski, Comparative Law in a Global Context: The Legal Systems of Asia and Africa (Cambridge, 2006). 
requirements of state law. Clearly, the government stands a greater likelihood of compelling compliance amongst minority Muslim populations by legalising previously informal transactions and bringing these into the regulatory light.

\section{THE MODUS OPERANDI OF REGULATING ALTERNATIVE FINANCE}

The government characterises its uniform regulatory approach to the development of Islamic finance in the United Kingdom as fair and consistent, rooted in the belief that no financial system deserves special treatment to the detriment of others. It states unequivocally that 'all financial institutions authorised by the FSA and operating in the UK, or seeking to do so, are subject to the same standards. This is true regardless of their country of origin, the sectors in which they wish to specialise, or their religious principles ... ${ }^{16}$ In essence, the government espouses a religiously 'neutral' position predicated on the establishment of a 'level playing field' for Islamic finance that is not distorted by tax and regulatory laws originally conceived for the conventional, interest-based system. ${ }^{17}$ As a result, since 2003 all legislative amendments to Acts of parliament including both finance and regulatory provisions refer to 'alternative financial instruments' when referring to general Islamic financial products and 'alternative investment bonds' when referring to Islamic bonds known as sukuk. Thus the religiously descriptive 'Islamic investments' is replaced with the ideologically neutral 'alternative financial instruments'. These usages are in line with a universalistic and uniform approach to the law, which emphasises the equal dignity of citizens and refrains from taking legislative positions on particular religious, cultural or value-embedded norms of minority populations. The FSA states that it would not be appropriate, even if it were possible, for the FSA to judge between different interpretations of Sharia law. ${ }^{18}$ Hence the FSA believes that neutrality can be achieved by avoiding any subjectivity or 'bias' and by focusing on concrete data (usually quantitative in nature) which can be understood in absolute terms and free of context. Moreover, a neutral position can be claimed between and vis-à-vis faith-based arguments. ${ }^{19}$

The utilisation of neutral language reflects the government's unease in transgressing the social consensus regarding the particular role of religion in the United Kingdom. This angst is expressed in government documents reaffirming the government's desire to create a 'level playing field', its repeated tendering of denials that it is granting 'special favours' and so forth. Therefore, the

16 M Ainley, A Mashayekhi, R Hicks, A Rahman and A Ravaliaet, Islamic Finance in the UK: Regulation and Challenges (London, 2007), p 11.

17 HM Treasury, The Development of Islamic Finance, p 13.

18 Ainley et al, Islamic Finance, p 13.

19 M Malik, 'Faith and the state of jurisprudence' in P Oliver (ed), Faith in Law: Essays in Legal Theory (Portland, 2000), pp 138-139. 
government takes no responsibility for problems of choice of evaluative criteria such as whether an Islamic financial product or service complies with the Sharia, just as it would not take a position on whether Christian investments were compatible with canon law. The state affirms that this would be 'inappropriate' as a 'secular' regulator. ${ }^{20}$

\section{THE RISK OF SHARIA NON-COMPLIANCE}

Individual financial institutions are wholly responsible for determining whether the products and services they offer comply with the principles and tenets of the Sharia. In accordance with the standard set by Accounting and Auditing Organisation for Islamic Financial Institutions, most Islamic financial institutions opt to form a Sharia supervisory board comprising three Sharia scholars trained in the classical Islamic laws of commerce, although others have chosen to use Sharia consultancy services or have merely hired a single Sharia advisor. The state takes no position on the composition, process, or credibility of such boards other than enforcing its rules regarding 'Approved Persons', which we examine below.

The FSA has expressed concern regarding the unique role of Sharia supervisory boards in Islamic financial institutions insofar as these entities are responsible for approving and legitimating the 'Islamic' products and services that originate from such institutions. Yet the state is essentially hamstrung from developing criteria and procedures to address the qualitative nature of the boards other than those employed to examine the corporate governance of conventional financial institutions. The FSA's focus centres on the role of the Sharia boards in each authorised firm, particularly its impact on the direction or operation of the firm. In particular, the FSA must determine whether Sharia scholars are assigned an executive role or whether they merely provide advisory services to the institution. According to the FSA Approved Persons rules, the suitability of anyone acting as a director is assessed according to 'fit and proper' criteria. For example, a criterion relates to the competence and capability of the candidate so that a prospective director would be expected to have relevant experience and education. In the case that a Sharia scholar's role does resemble that of an executive director, multiple memberships of different financial institutions' Sharia boards would be problematic due to significant conflicts of interest. Internationally, the practice of Sharia scholars sitting on multiple supervisory boards is a common, if not regular, occurrence. However, the FSA claims that FSA-authorised Islamic financial institutions to date have shown that Sharia scholars occupy advisory roles only so that their responsibilities do not interfere 
in the management of the firm. In evaluating the role of Sharia boards the FSA directs particular attention to the governance structure, fee structure, reporting lines as well as the terms and conditions of Sharia scholars' contracts. ${ }^{21}$ Furthermore, the state does not interfere in the affairs of Sharia boards after it has determined that Sharia board roles do not conflict in the management of the organisation.

Despite the state's inability to directly address Sharia-related aspects of the Sharia supervisory process, the FSA acknowledges that the unique role of Sharia scholars has potential implications for the solvency of Islamic financial institutions. In particular, the market's response to a breach of Sharia rules could dispel confidence in Islamic financial institutions as such assets would automatically be seen as liabilities and banks' solvency could be thrown into question. ${ }^{22}$ Yet the FSA's approach to regulating Islamic financial institutions largely ignores this central reputational risk.

\section{ISLAMIC FINANCIAL TRANSACTIONS BEFORE ENGLISH COURTS}

The competence and integrity of the Sharia supervisory process has been called into question in recent disputes before commercial courts. An English court recently heard an appeal between an Islamic financial institution, Kuwait's The Investment Dar, and the defendant, Lebanon's Blom Bank. ${ }^{23}$ The Investment Dar argued that it should not have to pay the Blom Bank a fixed return on deposits invested with it insofar as its articles of association prevent it from engaging in forbidden (haram) activities, ie interest (riba)-based activities. Ironically, The Investment Dar's Sharia board had approved the transaction and attempted to persuade an English judge that it did not do its job properly. ${ }^{24}$ Moreover, an earlier dispute involving an Islamic financial structure ${ }^{25}$ which represents the first purportedly 'Islamic' financial transaction tried in a Western court - illustrated a transaction that resembled a loan dressed up in Islamic garb. It too had been approved by the Islamic Investment Company's Sharia board and originally agreed by all parties to the dispute. Nonetheless, the defendants subsequently argued that the contract's contravention of the Sharia rendered the contract null and void. ${ }^{26}$ The court refused to try the case

Ainley et al, Islamic Finance, p 14.

Ibid, pp 18-19.

The Investment Dar v Blom Developments Bank [2009] EWHC 3545 (Ch).

A Cunningham, 'Role of Sharia boards needs modernisation', (2010) Financial Times 21 April.

Islamic Investment Company of the Gulf (Bahamas) Ltdv Symphony Gems N. Q Others [2002] All ER (D) 171 (Feb).

For example see JCT Chuah, 'Islamic principles governing international trade financing instruments: a study of the morabaha in English law', (2006-2007) 27 Northwestern Journal of International Law and Business 137-170 and HA Hamoudi, 'Jurisprudential schizophrenia: on form and function in Islamic finance', (2006-2007) 7 Chicago Journal of International Law 605- 
according to the Sharia as the contract expressly designated English law as the governing law of the contract.

\section{SHARIA'S ROLE AS A NON-STATE LAW}

Islamic finance has developed through cross-border commercial practice in the 'shadow of the law' ${ }^{27}$ insofar as the Sharia officially operates as the sovereign law of just one country; Saudi Arabia declares this officially. Other countries throughout the Middle East combine common or civil legal codes with Islamic law. The transnational origins of the field were recently highlighted in two authoritative cases before English courts: Beximco Pharmaceuticals Ltd $v$ Shamil Bank of Bahrain EC and Halpern and Others $v$ Halpern and Another establish clear precedents concerning the non-feasibility of the choice of a non-state law as the proper law of a contract. The courts held in both cases that the Rome Convention, an EU treaty whose provisions, in general, established the law governing contractual relations in the UK at the time these cases were heard, ${ }^{28}$ does not provide parties with a choice of a non-state body of law as the governing law of the contract. ${ }^{29}$ A subsidiary reflection of the court in Beximco held that the Sharia was not determinate enough to effectively govern commercial and financial transactions, a position that reflects English court judgments since the early decisions of Sheikh Abu Dhabi v Petroleum Ltd., ${ }^{30}$ Ruler of Qatar v International Marine Oil Company Ltd. ${ }^{31}$ and the famous 1958 Aramco v Government of Saudi Arabia $^{32}$ award. In each of these rulings, British magistrates held that the Sharia could not 'reasonably be said to exist', or it 'contains no precise rule' concerning a particular contract, so that Islamic law could not 'reasonably' be used as the governing law..$^{33}$ Muslim critics of these decisions argue that many legal systems entail similar difficulties and highlight the role that the Sharia plays in Middle Eastern litigation, and, especially in arbitration. ${ }^{34}$ Further, the Sharia's fundamental legal importance is evidenced in its inclusion in state constitutions as 'a source' or 'the source' throughout the Middle East. Consequently, it has

662. Both articles are highly critical of Islamic finance and accuse the industry of pursuing form over substance to the detriment of Islamic principles and ethics.

27 K Baelz, 'A murabaha transaction in an English court', (2004) 11 Islamic Law and Society 117. Baelz presents a very thorough and insightful analysis of the case.

28 The Rome Convention has since been superseded by the Rome I Regulation. However, Rome I also does not see any role for a non-state body of law as the governing law of a contract.

29 In particular, see Beximco Pharmaceuticals Ltd v Shamil Bank of Bahrain [2004] EWCA Civ 19. And the most recent related case: Halpern and Others $v$ Halpern and Another [2007] EWCA Civ 291.

30 Petroleum Development Ltd v Sheikh of Abu Dhabi [1951] 18 ILR 144.

31 Ruler of Qatar v International Marine Oil Company Ltd [1953] 20 Int LR 534.

32 Saudi Arabia v Arabian American Oil Co (Aramco) [1958] 27 Int LR 117.

33 I Fadlallah, 'Arbitration facing conflicts of culture: the 2008 Annual School of International Arbitration Lecture', (2009) 25 Arbitration International 305-306. Fadlallah presents a very interesting discussion of the general argument. Ibid. 
influenced countries' legal systems to varying degrees ${ }^{35}$ and, at any rate, occupies a very sacred position in the hearts and minds of Muslims throughout the world, whether they are devout or secular.

\section{CONCLUSION}

The state's authorisation of Islamic financial institutions could potentially facilitate the inclusion of large numbers of Britain's Muslim population in financial services markets that have heretofore avoided the conventional banking sector on the basis of their religious beliefs. Therefore, the Sharia-compliance of such institutions is at the heart of their decision to invest in Islamic financial products, and, as a result, creates a unique reputational risk associated with the industry. Yet the FSA, in its remit to create a level playing field amongst all financial services markets, is prevented from taking steps to advance the financial interests of one market over another; nor may it entertain religious interests in the secular practice of its regulatory responsibilities. Hence, the FSA is only indirectly able to address the risk of Sharia non-compliance through its Approved Persons rules. Furthermore, English courts have been unwilling to apply the Sharia in commercial disputes on the basis that the Rome Convention - now Rome I - precludes parties' choice of a non-state body of law as the governing law of their contract. Therefore, the risk of Sharia non-compliance continues unabated; a fact the state seems content to ignore.

The regulatory and legal treatment of Islamic finance in the UK throws light on the institutional basis - the values, norms and social purpose - of our governance structure. It also reveals a picture of society that is unwilling or unable on the basis of our created institutions - to tolerate a truly alternative system of finance. Therefore, the state is intent on garnering the economic and social benefits of Islamic finance, but it has no intention of making concessions that would prejudice the current regime.

doi:10.1017/So956618X10000827

35 W Ballantyne, 'The Shari'a and its relevance to modern transnational transactions' in Arab Comparative Q Commercial Law (London, 1987). Also, W Ballantyne, 'Commercial law: the conflict in shari'a and secular law' in S Behdad and F Nomani (eds), International Review of Comparative Public Policy (London, 1997). 